\title{
ANALISIS KESULITAN SISWA KELAS X SMA NEGERI 6 ACEH BARAT DAYA PADA MATERI TRIGONOMETRI
}

\author{
Nisya Fajri ${ }^{1}$, Ira Nida ${ }^{1}$ \\ ${ }^{1}$ STKIP Muhammadiyah Aceh Barat Daya, Jalan Nasional, Aceh Barat Daya, 23763, Indonesia \\ Email : nisya.fajri@gmail.com
}

\begin{abstract}
Abstrak
Hasil belajar siswa pada materi trigonometri masih berada dibawah nilai KKM dan nilai UN Matematika tahun 2017 pada materi Trigonometri masih sangat rendah. Tujuan penelitian ini untuk mengetahui jenis kesulitan belajar matematika pada materi Trigonometri. Metode penelitian ini menggunakan pendekatan kualitatif jenis deskriptif. Subyek dalam penelitian ini adalah 7 orang siswa kelas X pada SMA Negeri 6 Aceh Barat Daya. Data yang dikumpulkan berupa tes dan wawancara. Tes dilakukan untuk memetakan kesulitan siswa dan sebagai salah satu pertimbangan dalam pengambilan subyek, sedangkan wawancara untuk mengidentifikasi kesulitan siswa pada materi Trigonometri. Analisis data yang dilakukan melalui reduksi data, penyajian data, dan kesimpulan. Kesimpulan dari penelitian ini adalah siswa mengalami kesulitan pada materi trigonometri. Kesulitan dalam menggunakan konsep disebabkan kerena siswa tidak paham dalam mendefinisikan konsep trigonometri (sinus, cosinus, tangen). Kesulitan dalam memahami prinsip disebabkan karena siswa kesulitan dalam melakukan operasi hitung serta tidak bisa menentukan nilai perbandingan trigonometri pada sudut istimewa. Kesulitan dalam memecahkan masalah dalam bentuk verbal disebabkan karena siswa tidak mampu menunjukkan unsur yang diketahui dan ditanyakan dalam soal bentuk cerita. Oleh karena itu, hendaknya pemahaman konsep dasar bentuk akar, teorema pythagoras dan perbandingan dapat lebih diperkuat dalam pembelajaran.
\end{abstract}

Kata kunci: Analisis Kesulitan, Trigonometri

\begin{abstract}
The student learning outcomes are below the Minimum submission criteria value and the Low Mathematics national exam year 2017 in trigonometric materials so that the research aims to determine the type of difficulty of learning mathematics on the material Trigonometric. This method of research uses a qualitatively descriptive approach. The subjects in this study were 7 grade X students at SMA Negeri 6 Aceh Southwest. The Data is collected in the form of tests and interviews. Tests were conducted to map students ' difficulties and as one consideration in subjecttaking, while interviews to identify students ' difficulties in trigonometric materials. Data analysis is done through data reduction, data presentation, and conclusion. The conclusion of this study is that students have difficulty in trigonometric material. The difficulty in using the concept is due to students not understand the concept of trigonometry (sinus, cosine, tangent). Difficulty in understanding the principle is due to students difficulty in performing the calculating operation and not able to determine trigonometric comparison values at special angles. Difficulty in solving the problem in verbal form is because students are not able to show the known elements and asked questions in the form of the story. Therefore, it should be understanding the basic concepts of the root form, the Pythagorean theorems and the comparisons can be further strengthened in learning.
\end{abstract}

Keywords: Difficulty Analysis, Trigonometry 
Matematika merupakan salah satu mata pelajaran yang diberikan mulai dari sekolah dasar sampai dengan perguruan tinggi. Hal ini untuk membekali siswa dengan kemampuan berfikir logis, analitis, sistematis, kritis, dan kreatif. Matematika juga merupakan ilmu yang sangat berguna dalam kaitannya dengan perilaku kehidupan sehari-hari. Schoenfeld (Uno, 2009:110) mendefinisikan bahwa: "Belajar matematika berkaitan dengan apa dan bagaimana menggunakannya dalam membuat keputusan untuk memecahkan masalah. Matematika melibatkan pengamatan, penyelidikan, dan keterkaitannnya dengan fenomena fisik dan sosial." Matematika sebagai salah satu cabang ilmu yang perlu dipelajari, dipahami, dan dikuasai serta diperhatikan dalam pembelajaran karena matematika merupakan dasar dari ilmu pengetahuan dan teknologi.

Tujuan, materi, proses, dan penilaian pembelajaran matematika di kelas akan selalu menyesuaikan dengan tuntutan perubahan zaman. Sehubungan dengan hal ini, Gagne (Uno, 2009) menyatakan bahwa belajar matematika merupakan suatu kegiatan yang berkenaan dengan penyeleksian himpunan-himpunan dari unsur matematika yang sederhana dan merupakan himpunanhimpunan baru, yang selanjutnya membentuk himpunan-himpunan baru yang lebih rumit. Pembelajaran matematika dapat menata nalar siswa agar mereka menjadi siswa yang befikir kritis karena dalam proses pembelajaran matematika daya nalar siswa senantiasa diasah.

Kemampuan siswa dalam matematika dapat diketahui melalui asessment atau penilaian yang dilakukan, salah satunya melalui Ujian Nasional. Berdasarkan data Litbang Kemdikbud, nilai Ujian Nasional Matematika pada tahun 2017 masih sangat rendah. Pada tingkat sekolah nilai UN Matematika berada pada kategori D dengan nilai rata-rata sebesar 29,83, dan pada tingkat provinsi Aceh nilai UN Matematika berada pada kategori D dengan nilai rata-rata sebesar 33,39. Sedangkan, pada tingkat Nasional nilai UN Matematika juga masih berada pada kategori D dengan rata-rata sebesar 41,40. Hal ini menunjukkan bahwa nilai matematika masih jauh dari standar yang telah ditetapkan.

Berdasarkan hasil observasi awal yang dilakukan pada mata pelajaran matematika di kelas $\mathrm{X}$ SMA Negeri 6 Aceh Barat Daya pada bulan Oktober 2017, diketahui bahwa banyak siswa kesulitan dalam belajar matematika terutama mengenai materi Trigonometri. Siswa mengalami kesulitan pada penerapan rumus dalam menyelesaikan soal Trigonometri. Kebanyakan siswa hanya menghafal rumus dan cenderung belajar pada catatan yang diberikan oleh guru, akibatnya pemahaman yang diperoleh kurang memuaskan yang diketahui dari hasil nilai ulangan siswa masih berada dibawah Kriteria Ketuntasan Minimal (KKM) yang ditetapkan yaitu 70. Selain itu, kemampuan penguasaan materi Trigonometri siswa pada Ujian Nasional juga masih rendah yaitu 23,35 pada tingkat sekolah, dan 28,22 pada tingkat kabupaten.

Pemahaman konsep dalam pembelajaran matematika sebaiknya dikonstruksi dan ditemukan sendiri oleh siswa dengan menghubungkan pada konteks dunia nyata yang dikenal siswa sebagaimana dalam lampiran Permendikbud Nomor 58 tahun 2014 menyatakan bahwa pelajaran matematika bertujuan agar peserta didik memiliki kemampuan: 1) memahami konsep matematika, 2) menggunakan pola dalam penyelesaian masalah, 3) menggunakan penalaran matematika, 4) mengomunikasikan gagasan, 5) menghargai kegunaan matematika dalam kehidupan, 6) memiliki sikap dan perilaku sesuai nilai-nilai dalam matematika, 7) melakukan kegiatan motorik menggunakan pengetahuan matematika,dan 8) menggunakan alat peraga sederhana maupun hasil teknlogi dalam bermatematika. Selain itu, masalah kontekstual dalam pembelajaran matematika dapat digali melalui: (1) situasi personal siswa, yaitu yang berkenaan dengan kehidupan sehari-hari siswa, (2) situasi sekolah/akademik, yaitu berkaitan dengan kehidupan akademik di sekolah dan kegiatan-kegiatan dalam proses pembelajaran siswa, (3) situasi masyarakat, yaitu yang berkaitan dengan kehidupan dan aktivitas masyarakat sekitar siswa tinggal, dan (4) situasi saintifik/matematik, yaitu yang berkenaan dengan sains atau matematika itu sendiri.

Matematika merupakan suatu sarana untuk memecahkan masalah kehidupan sehari-hari. Mempelajari matematika memerlukan wawasan yang luas dan pemikiran yang logis karena dalam mempelajarinya tidak cukup dengan membaca saja. Bahasa yang digunakan dalam matematika merupakan bahasa simbol yang berlaku secara umum dan penuh arti. Untuk itu kita perlu pemahaman 
yang lebih jauh tentang suatu konsep dalam matematika. Dalam mempelajari matematika siswa mampunyai dasar kesulitan khusus. Sehubungan dengan itu Soejono (1984) mengemukakan sebagai berikut:

a. Kesulitan dalam menggunakan konsep

1.) Siswa lupa nama singkatan/nama teknik suatu objek

2.) Ketidakmampuan mengingat satu atau lebih syarat cukup dan sebagainya

b. Kesulitan belajar dalam menggunakan prinsip

1.) Siswa tidak mempunyai konsep yang dapat digunakan untuk mengembangkan prinsip sebagai butir pengetahuan baru

2.) Siswa tidak menggunakan prinsip karena kurang kejelasan tentang prinsip tersebut dan sebagainya

c. Kesulitan dalam memecahkan masalah berbentuk verbal

1.) Tidak mengerti apa yang dibaca akibat kurangnya pengetahuan siswa tentang konsep atau beberapa istilah yang tidak diketahui

2.) Tidak mampu menetapkan variabel untuk persamaan dan sebagainya.

Banyak faktor penyebab kesulitan belajar. Sebagaimana yang diungkapkan oleh Kesulitan siswa dalam belajar matematika memiliki karakter tersendiri. Karakteristik siswa berkesulitan belajar matematika menurut Lerner (Abdurachman, 1996) yaitu: 1) adanya gangguan dalam hubungan keruangan seperti atas bawah, puncak dasar, tinggi rendah, depan belakang, dan awal akhir; 2) abnormalitas persepsi visual seperti kesulitan melihat berbagai obyek dalam hubungannya dengan kelompok; 3) asosiasi visual motor yaitu tidak dapat menghitung benda-benda secara terurut; 4) perseverasi yang merupakan gangguan perhatian siswa yang melekat pada satu obyek dalam waktu yang relatif lama; 5) kesulitan mengenal dan memahami simbol, 6) gangguan penghayatan tubuh; 7) kesulitan dalam bahasa dan membaca yaitu kesulitan dalam menyelesaikan soal dalam bentuk cerita; dan 8) score Performance IQ jauh lebih rendah daripada skor verbal IQ.

Kesulitan siswa dalam belajar matematika dapat mengakibatkan kesalahan dalam menyelesaikan permasalahan matematika, salah satunya pada materi trigonometri. Sebagaimana pendapat Abidin (2012), kesalahan-kesalahan yang sering terjadi dalam menyelesaikan soal trigonometri adalah kesalahan fakta, kesalahan keterampilan, kesalahan konsep, dan kesalahan prinsip. Hal senada juga diungkapkan oleh Widodo dan Sujadi (2015) bahwa kesalahan yang sering terjadi dalam penyelesaian masalah trigonometri adalah kesalahan konsep, kesalahan perhitungan, serta kesalahan kebiasaan dan penegasan jawaban. Sehingga dapat dikatakan bahwa siswa yang salah dalam menyelesaikan soal trigonometri sedang mengalami kesulitan dalam menyelesaikan masalah trigonometri.

Berdasarkan uraian diatas, dapat dijelaskan bahwa konsep merupakan pemahaman dasar dari suatu masalah tertentu untuk mengetahui suatu hal secara lebih jelas dalam memecahakn suatu masalah. Sedangkan prinsip merupakan gabungan beberapa konsep dasar yang dapat digunakan untuk mengembangkan konsep tersebut. Guru yang mengajar siswa berkesulitan belajar matematika hendaknya mampu mendeteksi berbagi tipe kesulitan siswa seperti yang telah dikemukakan sebelumnya.

Mengingat pentingnya mengkaji kesulitan siswa dalam belajar matematika khususnya pada materi trigonometri sebagaimana peraturan Menteri Pendidikan Nasional RI No 23 Tahun 2006 yang menetapkan bahwa Trigonometri sebagai salah satu materi yang diajarkan pada jenjang Sekolah menengah atas, maka perlu dilakukan penelitian untuk menganalisis kesulitan siswa dalam menggunakan konsep, memahami prinsip dan memecahkan masalah dalam bentuk verbal.

\section{METODE PENELITIAN}

\section{Rancangan Penelitian}

Metode dalam penelitian ini menggunakan pendekatan kuatitatif jenis deskriptif. Subyek dalam penelitian ini adalah tujuh dari 21 siswa kelas X SMA Negeri 6 Aceh Barat Daya pada tahun pelajaran 2017/2018 semester genap. Pertimbangan dalam pemilihan subyek berdasarkan kriteria, yaitu 1) siswa siswa yang telah mengikuti tes materi Trigonometri, 2) jawaban siswa mewakili indikator kesulitan 
menggunakan konsep, kesulitan menggunakan prinsip serta kesulitan memecahkan masalah dalam bentuk verbal (soal cerita), 3) siswa yang kooperatif untuk diwawancarai, dan 4) serta siswa yang dijamin originalitas jawabannya.

Data dikumpulkan melalui tes dan wawancara. Tes diberikan dalam bentuk uraian sebanyak lima buah soal yang disusun untuk memetakan kesulitan belajar matematika siswa dalam menggunakan konsep, memahami prinsip dan memecahakan soal dalam bentuk verbal pada materi trigonometri. Data dianalisis melalui reduksi data, penyajian data, dan kesimpulan. Data yang diperoleh selanjutnya ditriangulasi menggunakan triangulasi waktu.

Setiap subyek diwawancarai dan diminta untuk menyelesaikan masalah (soal tes) langsung dihadapan peneliti. Pengujian kredibilitas data dilakukan dengan triangulasi waktu yaitu memberikan masalah yang setara dengan soal tes pada setiap subyek di waktu yang berbeda yang dilakukan pada saat wawancara kedua. Berdasarkan triangulasi waktu diperoleh kesimpulan bahwa adanya konsistensi jawaban setiap subyek dalam menyelesaikan masalah soal tes dan masalah yang setara soal tes.

\section{HASIL PENELITIAN DAN PEMBAHASAN}

Pelaksanaan penelitian ini dilakukan setelah materi trigonometri diajarkan oleh guru bidang studi dan peneliti hanya memberikan tes kepada siswa. Penelitian ini dilakukan pada semester genap tahun ajaran 2017/208. Data yang diperoleh berupa hasil pemberian tes dan hasil wawancara dengan 7 (tujuh) siswa yang mengalami kesulitan dalam menyelesaikan soal-soal trigonometri.

\section{Kesulitan Soal Nomor 1}

Kesulitan siswa yang dialami siswa pada soal nomor 1 yaitu kesulitan dalam menggunakan konsep yang dialami oleh 12 orang siswa. Kesulitan yang dialami yaitu ketidakmampuan untuk mengingat suatu kondisi yang cukup bagi suatu obyek untuk dinyatakan dengan istilah yang mewakili konsep tersebut. Berikut disajikan contoh jawaban siswa nomor 1 dalam mengalami kesulitan dalam menggunakan konsep.

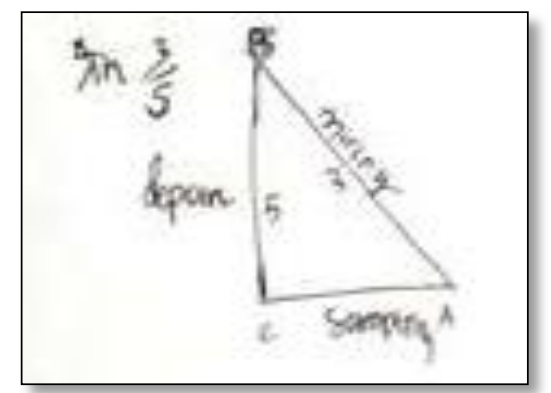

Gambar 1. Jawaban siswa S10 yang mengalami kesulitan menggunakan konsep

Pada soal nomor 1, siswa diminta untuk menentukan nilai $\cos \propto$ dan $\tan \propto$ jika $\sin \propto=\frac{3}{5}$ dan $0^{\circ}<\propto<90^{\circ}$. Namun, dalam contoh jawaban siswa pada gambar 1 di atas, siswa terlihat kesulitan dalam memberikan konsep mana yang digunakan. Seharusnya, siswa menggambarkan terlebih dahulu segitiga yang sesuai dengan perbandingan trigonometri yang dimaksud. Setelah itu, baru digunakan konsep teorema pythagoras untuk menentukan sisi yang lainnya. Berikut prosedur penyelesaiannya.

Sin $\mathrm{a}=\frac{3}{5}$ dapat digambarkan pada segitiga siku-siku. Dengan mengingat definisi bahwa sinus adalah hasil bagi sisi di hadapan sudut dengan sisi terpanjang, maka untuk $\sin \mathrm{a}=\frac{3}{5}$ berlaku:

$$
\frac{\text { sisi di hadapan sudut }}{\text { sisi terpanjang }}=\frac{3}{5}
$$




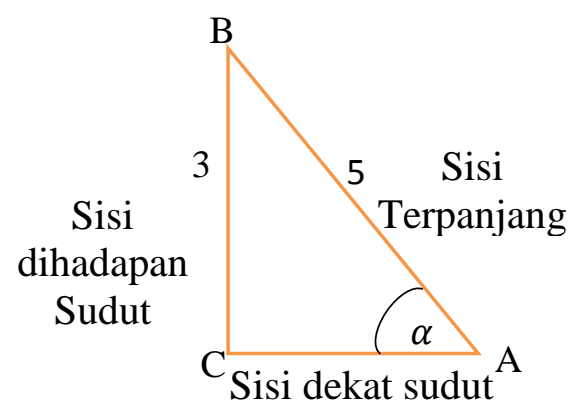

dengan menggunakan teorema pythagoras, $\mathrm{AC}$ dapat ditentukan, yaitu:

$$
\mathrm{AC}=\sqrt{(\mathrm{AB})^{2}-(\mathrm{BC})^{2}}=\sqrt{5^{2}-3^{2}}=\sqrt{16}=
$$

Dengan demikian:

$$
\begin{aligned}
& \cos \alpha=\frac{\mathrm{AC}}{\mathrm{AB}}=\frac{4}{5} \\
& \tan \alpha=\frac{\mathrm{BC}}{\mathrm{AC}}=\frac{3}{4}
\end{aligned}
$$

\section{Kesulitan Soal Nomor 2}

Beberapa siswa mengalami kesulitan dalam menggunakan konsep dan prinsip pada soal nomor 2 yaitu 11 orang siswa mengalami kesulitan dalam menggunakan konsep dan 4 orang siswa mengalami kesulitan dalam memahami prinsip. Berikut disajikan salah satu contoh jawaban siswa yang mengalami kesulitan dalam menggunakan konsep dan prinsip.

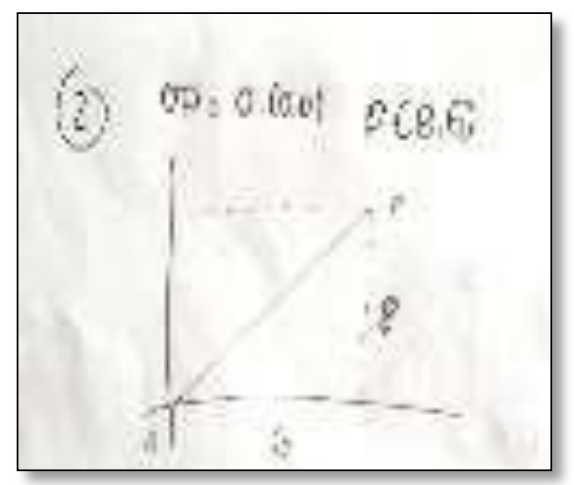

Gambar 2. Jawaban siswa S10 yang mengalami kesulitan menggunakan konsep

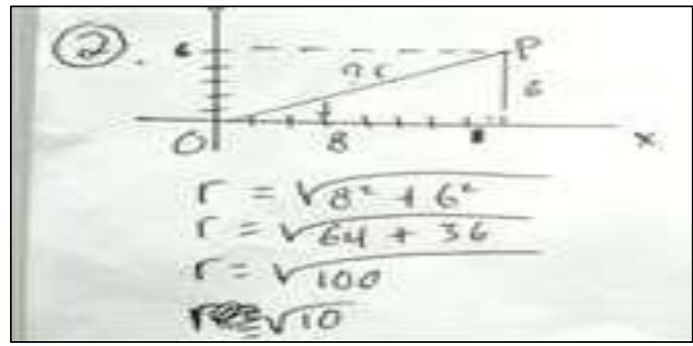

Gambar 3. Jawaban siswa S1 yang mengalami kesulitan memahami prinsip 
Pada soal nomor 2, siswa diminta untuk menentukan perbandingan trigonometrinya (sinus, cosinus dan tangen) pada garis OP dengan $\mathrm{O}(0,0)$ dan $\mathrm{P}(8,6)$ yang membentuk sudut $\alpha$ terhadap sumbu X positif. Dari hasil jawaban siswa di atas, terlihat bahwa pada gambar 2 siswa kesulitan dalam menggunakan konsep untuk menyelesaiakan soal yang diminta. Siswa melakukan kesalahan dalam menentukan titik $\mathrm{P}(8,6)$, hanya menggambarkan saja tanpa ada penyelesaian. Sedangkan pada gambar 3, siswa telah menggunakan konsep yang benar. Namun, siswa mengalami kesulitan memahami prinsip dari soal yang diberikan. Terlihat siswa tidak dapat menunjukkan penyelesaian selanjutnya dari keterangan yang diberikan. Adapun prosedur penyelesaian yang benar sebagai berikut.

Perhatikan gambar berikut ini!

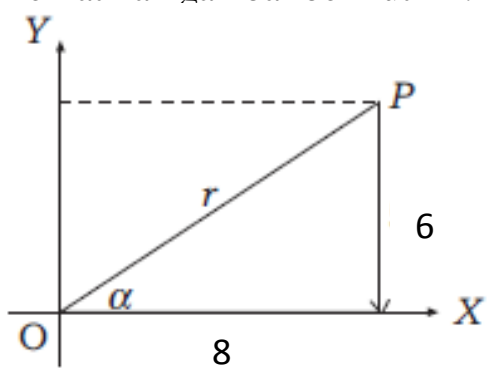

$$
\begin{aligned}
& r=\sqrt{8^{2}+6^{2}} \\
& r=\sqrt{8^{2}+6^{2}} \\
& r=\sqrt{64+36} \\
& r=\sqrt{100} \\
& r=10
\end{aligned}
$$

Setelah diperoleh nilai r, maka perbandingan trigonometrinya adalah:

$\tan \alpha=\frac{6}{8} \quad \sin \alpha=\frac{6}{10} \quad \cos \alpha=\frac{8}{10}$

Dari hasil tes di atas, dapat disimpulkan bahwa siswa mengalami kesulitan konsep dan prinsip dalam menyelesaikan soal nomor 2. Siswa terlihat kebingungan dalam menggunakan konsep yang tepat untuk menerjemahkan gambar yang telah dibuat agar dapat ditentukan perbandingan trigonometrinya pada soal nomor 2. Adapun kesalahan prinsip yang dilakukan siswa merupakan konsep akar yang harus dikuasai siswa sebaik mungkin karena sering ditemukan pada konsep matematika lainnya.

\section{Kesulitan Soal Nomor 3}

Beberapa siswa mengalami kesulitan dalam memahami konsep dan prinsip pada soal nomor 3 yaitu ada 17 orang siswa yang mengalami kesulitan menggunakan konsep dan 4 orang siswa mengalami kesulitan memahami prinsip. Berikut disajikan salah satu contoh jawaban siswa yang mengalami kesulitan tersebut.

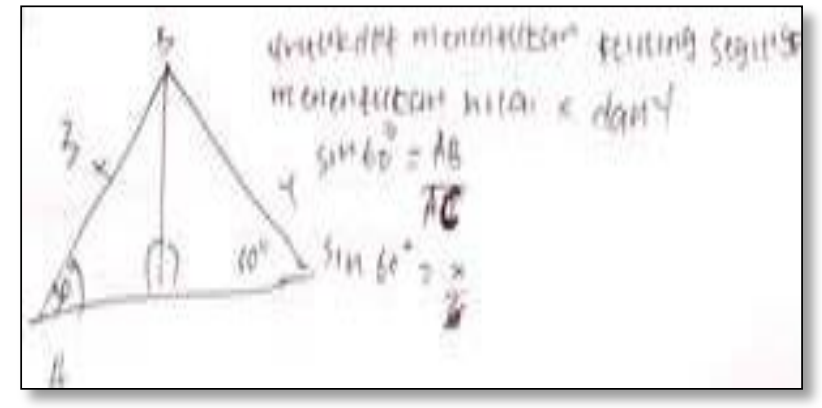

Gambar 4. Jawaban siswa S13 yang mengalami kesulitan menggunakan konsep

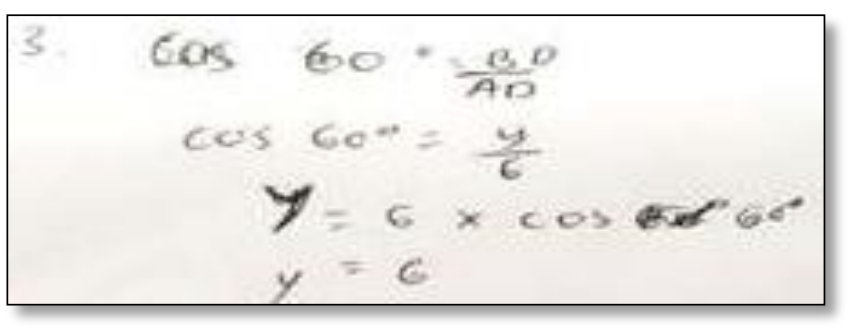


Gambar 5. Jawaban siswa S5 yang mengalami kesulitan dalam memahami prinsip

Pada soal nomor 3, siswa diminta untuk menentukan keliling segitiga $\mathrm{ABD}$ dengan $\angle \mathrm{B}=90^{\circ}$, $\angle \mathrm{A}=30^{\circ}, \mathrm{AD}=6 \mathrm{~cm}$ danBC adalah garis tinggi yang memotong AD.Dari hasil jawaban siswa di atas, pada gambar 4 terlihat bahwa siswa salah dalam menggunakan konsep yang benar sehingga hasil yang diberikanpun keliru. Sedangkan pada gambar 5 terlihat bahwa siswa telah menggunakan konsep yang benar. Namun, siswa mengalami kesulitan memahami prinsip dari soal yang diberikan. Terlihat siswa tidak dapat menunjukkan penyelesaian selanjutnya dari keterangan yang diberikan. Adapun prosedur penyelesaian yang benar sebagai berikut.

Secara lengkap informasi tentang segitiga ABD seperti pada gambar di bawah ini:

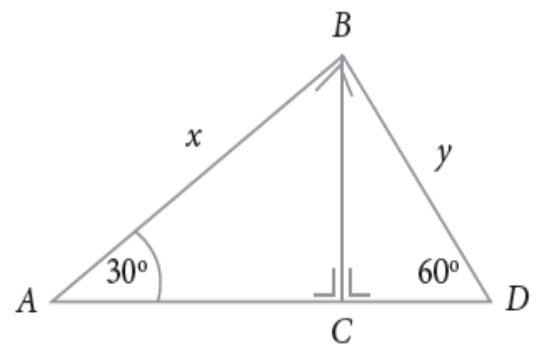

Untuk dapat menentukan keliling segitiga, harus menemukan nilai $\mathrm{x}$ dan $\mathrm{y}$. Perhatikan $\triangle \mathrm{ABD}$, diketahui bahwa:

$$
\begin{array}{l|l}
\sin 60^{\circ}=\frac{A B}{A D} & x=6 \times \sin 60^{\circ} \\
\sin 60^{\circ}=\frac{x}{6} & x=6 \times \frac{\sqrt{3}}{2} \rightarrow x=3 \sqrt{3}
\end{array}
$$

$$
\begin{aligned}
\cos 60^{\circ} & =\frac{\mathrm{BD}}{\mathrm{AD}} \\
\cos 60^{\circ} & =\frac{\mathrm{y}}{6} \\
y & =6 \times \cos 60^{\circ} \\
y & =6 \times \frac{1}{2} \\
y & =3
\end{aligned}
$$

Jadi, keliling segitiga $A B D=A B+B D+A D$

Dari hasil tes di atas, siswa kembali mengalami kesulitan yang sama seperti pada soal nomor 1. Konsep dari perbandingan trigonometri belum dikuasai siswa dengan baik. Siswa masih mengalami kesulitan dalam menerjemahkan sisi depan, sisi pada sudut dan hepotenusa pada segitiga siku-siku.

\section{Kesulitan Soal Nomor 4}

Beberapa siswa banyak mengalami kesulitan dalam memahami konsep, prinsip dan kesulitan dalam memecahkan masalah dalam bentuk verbalpada soal nomor 4 yaitu ada 2 orang siswa yang mengalami kesulitan menggunakan konsep, 3 orang siswa mengalami kesulitan memahami prinsip dan 6 orang siswa mengalami kesulitan dalam memecahkan masalah dalam bentuk verbal. Berikut contoh jawaban siswa yang disajikan pada gambar berikut ini : 


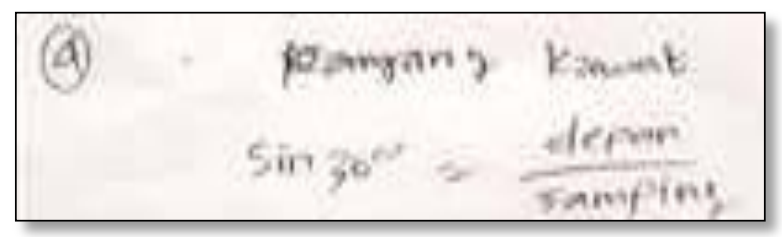

Gambar 6. Jawaban siswa S9 yang mengalami kesulitan menggunakan konsep

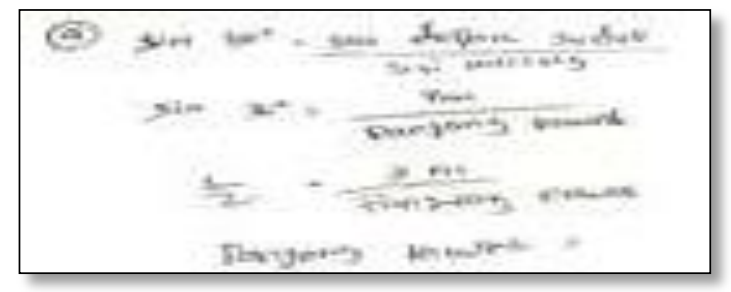

Gambar 7. Jawaban siswa S5 yang mengalami kesulitan dalam memahami prinsip

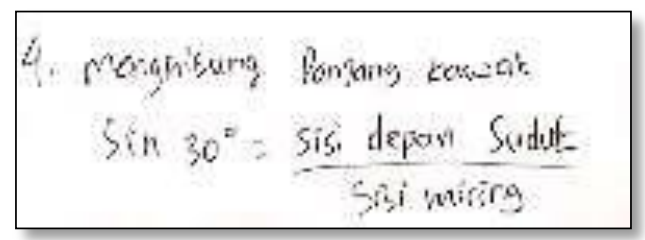

Gambar 8. Jawaban siswa S16 yang mengalami kesulitan dalam memecahkan masalah dalam bentuk verbal

Pada gambar di atas, terlihat bahwa siswa tidak mampu menguraikan dengan baik unsur yang diketahui dan solusi dari pernyataan pada soal berbentuk cerita pada soal nomor 4. Pada soal nomor 4, siswa diminta untuk menentukan panjang kawat dari sebuah antena dipasang dengan diberi penguat dari kawat, jika tinggi antena $7 \mathrm{~m}$ dan sudut elevasi $30^{\circ}$. Siswa hanya memberikan konsep perbandingan trigonometri, tetapi tidak dapat mengaitkan dengan soal yang diberikan. Adapun prosedur yang benar dari jawaban soal nomor 4 sebagai berikut.

Menghitung panjang kawat dengan menggunakan perbandingan trigonometri sinus $30^{\circ}$ sebagai berikut.

$$
\begin{aligned}
\sin 30^{\circ} & =\frac{\text { sisi depan sudut }}{\text { hepotenusa }} \\
\sin 30^{\circ} & =\frac{7 \mathrm{~m}}{\text { panjang kawat }} \\
\frac{1}{2} & =\frac{7 \mathrm{~m}}{\text { panjang kawat }}
\end{aligned}
$$

Panjang kawat $=7 \mathrm{~m} \times 2$

Panjang kawat $=14 \mathrm{~m}$

Jadi, panjang kawat dari tiang tersebut adalah $14 \mathrm{~m}$.

Dari hasil tes di atas, dapat disimpulkan bahwa siswa mengalami kesulitan verbal sehingga kesulitan dalam menggunakan konsep yang tepat, siswa tidak mampu menerjemahkan soal yang berbentuk cerita dengan baik. Sehingga keliru dalam menggunakan konsep untuk memecahkan masalah pada soal nomor 4 . 


\section{Kesulitan Soal Nomor 5}

Beberapa siswa banyak mengalami kesulitan dalam memahami konsep, prinsip dan kesulitan dalam memecahkan masalah dalam bentuk verbal pada soal nomor 5 yaitu ada 4 orang siswa yang mengalami kesulitan menggunakan konsep, 7 orang siswa mengalami kesulitan memahami prinsip dan 8 orang siswa mengalami kesulitan dalam memecahkan masalah dalam bentuk verbal. Berikut contoh jawaban siswa yang disajikan pada gambar berikut ini.

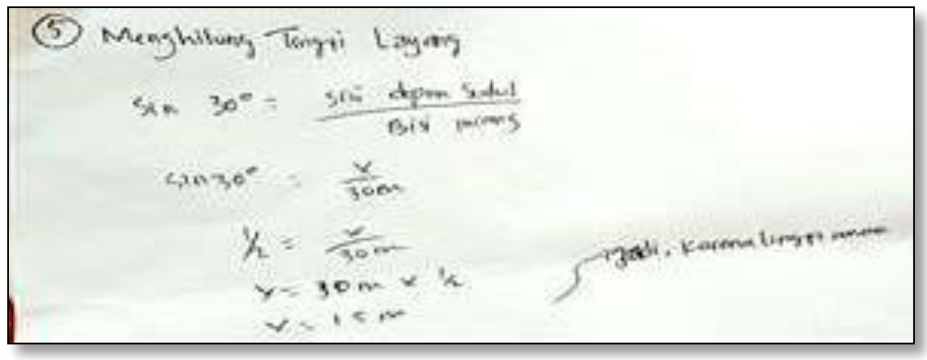

Gambar 9. Jawaban siswa S9 yang mengalami kesulitan menggunakan konsep

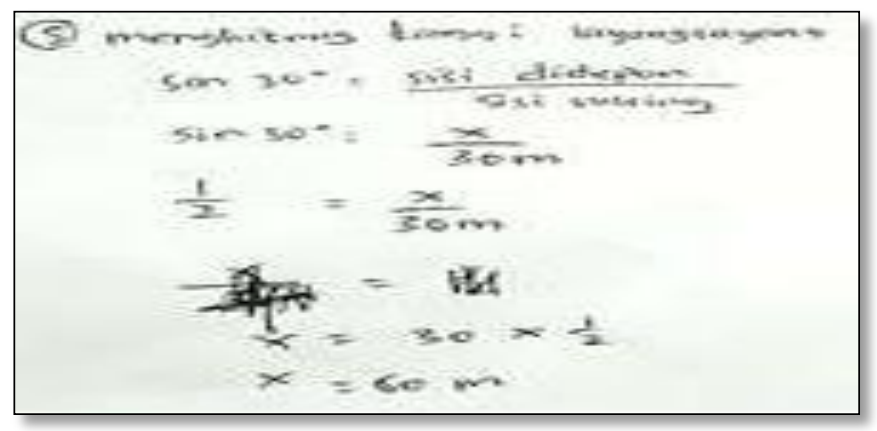

Gambar 10. Jawaban siswa S2 yang mengalami kesulitan memahami prinsip

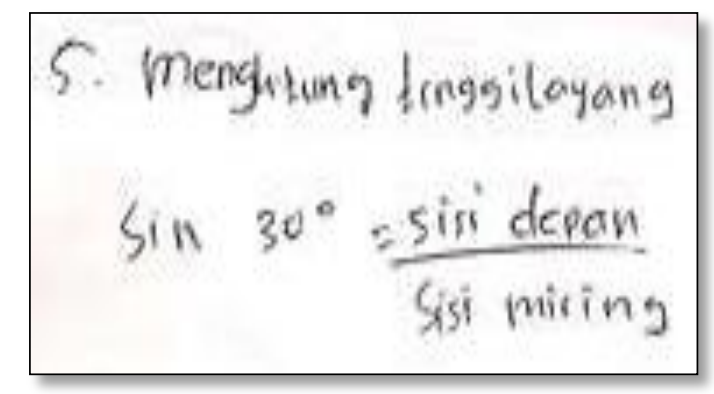

Gambar 4.11 Jawaban siswa S16 yang mengalami kesulitan dalam memecahkan masalah dalam bentuk verbal

Pada gambar di atas, sama seperti pada soal nomor 4 yang telah diuraikan sebelumnya, terlihat bahwa siswa tidak mampu menguraikan dengan baik unsur yang diketahui dan solusi dari pernyataan pada soal berbentuk cerita pada soal nomor 5. Pada soal nomor 5, siswa diminta untuk menentukan tinggi layang-layang yang diterbangkan seorang anak yang mempunyai tinggi 1,5 meter dengan panjang benang 30 meter. Sudutyang dibentukantara benang layang-layang yang terbang dengan garis horizontal adalah $30^{\circ}$. Siswa hanya memberikan konsep perbandingan trigonometri, tetapi tidak dapat mengaitkan dengan soal yang diberikan. Adapun prosedur yang benar dari jawaban soal nomor 5 sebagai berikut.

Menghitung tinggi layang-layang dengan menggunakan perbandingan trigonometri sinus $30^{\circ}$ sebagaiberikut. 


$$
\begin{aligned}
\sin 30^{\circ} & =\frac{\text { sisi depan sudut }}{\text { hepotenusa }} \\
\sin 30^{\circ} & =\frac{\mathrm{x}}{30 \mathrm{~m}} \\
\frac{1}{2} & =\frac{\mathrm{x}}{30 \mathrm{~m}} \\
\mathrm{x} & =30 \mathrm{~m} \times \frac{1}{2} \\
\mathrm{x} & =15 \mathrm{~m}
\end{aligned}
$$

Jadi, karena tinggi anak 1,5 meter, maka tinggi layang-layang di atas permukaan tanah adalah $\mathrm{x}+1,5$ $\mathrm{m}=15 \mathrm{~m}+1,5 \mathrm{~m}=15,5$ meter.

Dari hasil tes di atas, dapat disimpulkan bahwa siswa kesulitan dalam menerapkan konsep perbandingan trigonometri dalam menyelesaikan soal nomor 5 tentang tinggi layang-layang. Siswa kesulitan dalam memahami soal berbentuk verbal, sama seperti pada soal nomor 4 .

Dari hasil analisis data penelitian didapat informasi bahwa kemampuan siswa dalam menyelesaikan soal materi trigonometri masih dibawah kriteria ketuntasan minimal yaitu 70. Hal ini dikarenakan siswa masih mengalami kesulitan dalam menyelesaikan soal yang diberikan. Dari 5 soal yang diberikan banyak siswa yang salah dalam menjawab soal yang diberikan mengenai materi trigonometri.

Hasil analisis kesulitan siswa dalam menyelesaikan soal matematika pada materi trigonometri diperoleh bahwa siswa mengalami kesulitan dalam menggunakan konsep, kesulitan dalam memahami prinsip dan kesulitan dalam memecahkan masalah dalam bentuk verbal.Kesulitan dalam menggunakan konsep banyak dialami siswa pada soal nomor 3 yaitu sebesar 80,95\%, kesulitan dalam memahami prinsip banyak dialami siswa pada soal nomor 5 yaitu sebesar $42,86 \%$ dan kesulitan dalam memecahkan masalah dalam bentuk verbal banyak dialami siswa pada soal nomor 5 sebesar 38,10\%. Kesulitan yang paling banyak dialami siswa adalah kesulitan konsep, karena dialami siswa dengan rata-rata $42,86 \%$. Sedangkan kesulitan prinsip paling seidkit dialami siswa yaitu dengan rata-rata sebesar $19,05 \%$.

Kesulitan yang dialami siswa tersebut terlihat dari banyaknya kesalahan yang dilakukan dalam menyelesaikan soal trigonometri. Khususnya pada soal nomor 4 dan 5, karena menuntut kemampuan siswa dalam memahami soal cerita yang diberikan. Untuk mengatasi kesulitan ini, siswa harus terbiasa dalam mengerjakan soal-soal matematika khususnya pada materi trigonometri sehingga

\begin{tabular}{|c|c|c|}
\hline No & Kesulitan siswa & Indikator \\
\hline 1 & $\begin{array}{l}\text { Kesulitan konsep: } \\
\text { - Siswa tidak paham dalam } \\
\text { mendefinisikan konsep trigonometri } \\
\text { (sinus, cosinus, tangen) }\end{array}$ & $\begin{array}{l}\text { Siswa membuat definisi yang keliru pada } \\
\text { sinus. Siswa membuat: } \\
\sin A=\frac{\text { sisi miring }}{\text { sisi depan sudut }} \\
\text { Definisi yang benar adalah: } \\
\sin A=\frac{\text { sisi depan sudut }}{\text { hepotenusa }}\end{array}$ \\
\hline
\end{tabular}
kesulitan yang dialami dapat diminimalisir.

Untuk lebih jelasnya mengenai kesulitan yang dialami siswa berdasarkan analisis yang telah dilakukan dapat disajikan pada tabel 4.4 berikut ini.

Tabel 1. Kesulitan Siswa dalam Menyelesaikan Soal Trigonometri 


\begin{tabular}{|c|c|c|}
\hline 2 & $\begin{array}{l}\text { Kesulitan prinsip: } \\
\text { - Kesalahan dalam melakukan operasi } \\
\text { hitung } \\
\text { - Tidak bisa menentukan nilai } \\
\text { perbandingan trigonometri pada sudut } \\
\text { istimewa. }\end{array}$ & $\begin{array}{l}\text { Dalam melakukan operasi perhitungan akar, } \\
\text { siswa membuat kesalahan prinsip. Siswa } \\
\text { membuat } \sqrt{100}=\sqrt{10} \text { seharusnya } \sqrt{100}= \\
10 \text {. } \\
\text { Pada sudut istimewa, siswa tidak bisa } \\
\text { menentukan nilai cos } 60^{\circ}\end{array}$ \\
\hline 3 & $\begin{array}{l}\text { Kesulitan verbal: } \\
\text { - } \quad \text { Siswa tidak mampu menunjukkan unsur } \\
\text { yang diketahui dalam soal bentuk cerita. }\end{array}$ & $\begin{array}{l}\text { Pada soal nomor 5, siswa hanya menjawab } \\
\qquad \sin 30^{\circ}=\frac{\text { sisi depan }}{\text { sisi miring }}\end{array}$ \\
\hline
\end{tabular}

\section{KESIMPULAN}

Berdasarkan hasil penelitian dan pembahasan, dapat disimpulkan bahwa siswa mengalami kesulitan dalam menggunakan konsep, kesulitan dalam memahami prinsip dan kesulitan dalam memecahkan masalah dalam bentuk verbal. Kesulitan dalam menggunakan konsep banyak dialami siswa pada soal nomor 3 yaitu sebesar $80,95 \%$ kerena siswa tidak paham dalam mendefinisikan konsep trigonometri (sinus, cosinus, tangen). Kesulitan dalam memahami prinsip banyak dialami siswa pada soal nomor 5 yaitu sebesar $42,86 \%$ karena siswa kesulitan dalam melakukan operasi hitung serta tidak bisa menentukan nilai perbandingan trigonometri pada sudut istimewa. Kesulitan dalam memecahkan masalah dalam bentuk verbal banyak dialami siswa pada soal nomor 5 sebesar $38,10 \%$ karena siswa tidak mampu menunjukkan unsur yang diketahui dalam soal bentuk cerita. Kesulitan yang paling banyak dialami siswa adalah kesulitan konsep, karena dialami siswa dengan rata-rata $42,86 \%$. Sedangkan kesulitan prinsip paling sedikit dialami siswa yaitu dengan rata-rata sebesar $19,05 \%$.

Berdasarkan kesimpulan diatas, peneliti merekomendasikan agar dalam upaya meningkatkan kualitas pembelajaran matematika di sekolah guru dapat memberikan atau menguatkan konsep dasar bentuk akar, teorema pythagoras dan perbandingan.

\section{REFERENCES}

Abdurachman, Mulyono. (1996). Pendidikan Bagi Anak Berkesulitan Belajar. Jakarta: Depatemen Pendidikan dan Kebudayaan, Direktorat Jenderal Pendidikan Tinggi, Proyek Pendidikan Tenaga Akademik.

Abidin, Zainal. (2012). Analisis Kesalahan Mahasiswa Prodi Pendidikan Matematika Fakultas Tarbiayah IAIN Ar-Raniry dalam Mata Kuliah Trigonometri dan Kalkulus 1. Jurnal Ilmiah DIDAKTIKA, 1(XIII). 183-196.

Soejono. (1984). Diagnosis Kesulitan dan Pengajaran Remedial Matematika. Jakarta: P2LPTK

Uno, Hamzah B. (2009). Teori motivasi dan Pengukurannya (Analisis di Bidang Pendidikan). Jakarta: Bumi Aksara.

Widodo, Sri, Adi., Sujadi, A,A. (2015). Analisis Kesalahan Mahasiswa dalam Memecahkan Masalah Trigonometri. Jurnal Sosiohumaniora. 1(I). 51-63 